\title{
SENTIMENT AND CONFIDENCE IN FINANCIAL ENGLISH: A CORPUS STUDY
}

\author{
J. Lachlan Mackenzie \\ Vrije Universiteit Amsterdam (VU University) \\ De Boelelaan 1105, 1081 HV Amsterdam, The Netherlands
}

\begin{abstract}
In the financial world, the words sentiment and confidence are frequently employed to invoke the feelings of an individual investor or of investors in general about the future movement of a share or of the stock market in general. The article focuses on the use of the two words in financial journalism by examining all instances of sentiment and confidence in the on-line Hong Kong Financial Services Corpus and explores the hypothesis that they will differ from each other in line with how they are deployed in ordinary usage. Drawing inspiration from functionally-oriented semantics and Appraisal Theory, the core of the article reveals how the two words are employed in clauses and noun phrases in the corpus. Our findings reveal that sentiment and confidence are to a very large extent used in financial parlance as though they were synonymous. The use of these terms reflects the writers' awareness of the role of emotions as a vital constituent factor in decision-making.
\end{abstract}

Keywords: confidence, emotion, financial analysis, grammar, journalism, semantics, sentiment

\section{INTRODUCTION}

This article is concerned with how financial journalists and other writers of texts about finance formulate their expectations about the future development of stocks and shares by using two words from "emotion talk" (Bednarek 2008), the uncountable nouns sentiment and confidence. The specific aim is to provide a detailed analysis of their occurrence in a corpus of Financial English and to establish whether in this register the two nouns, which in general usage have non-overlapping meaning definitions, show distinct semantico-syntactic distributions and collocations. The article begins with an introduction to the type of discourse to be at the focus of the discussion, financial journalism $(\S 2)$. It then presents a brief overview of the treatment of emotions on the stock market from the viewpoints of psychology and discourse analysis ( $§ 3)$. The next section $(\S 4)$ is devoted to describing the use of the words sentiment and confidence in general parlance with reference to the Oxford English Dictionary $(O E D)$ and WordNet. This leads in $\S 5$ to a brief overview of the treatment of confidence in Appraisal Theory (Martin and White 2005, Bednarek 2008). The hypothesis that follows from $\S \S 4-5$ is formulated in $\S 6$. After a brief description of the corpus in $\S 7$, the following sections are devoted to in-depth descriptions of the occurrence of sentiment $(\S 8)$ and confidence $(\S 9)$ in the corpus. The article ends with a discussion that evaluates the hypothesis in the light of the data $(\S 10)$ and a conclusion $(\S 11)$. 


\section{EMOTIONS AND THE FINANCIAL MARKETS}

It is hardly any wonder that stock markets, where shares and other financial products are bought and sold and where fortunes can be made or lost, are an arena of strong emotions. For this reason, the advice given to novices who first venture into the realm of financial trading is to keep a cool head and to make rational choices, basing their decisions on companies' past performance, objective facts about the current economic situation and thoroughly argued and documented prognoses of future trends. This tension between emotion and reason has given rise to a huge contingent of financial analysts who use computer modelling and other techniques to distil emotion-free prognostications about share prices from which the human factor, seen as a propensity to take snap decisions to buy or sell on the basis of impulses and gut feelings, is banished. This quest for reliable and objective information has fed into the large branch of financial journalism that not only reports on the facts and figures emerging from listed companies (i.e. those whose shares are traded on national stock markets) but also reflects the opinions of reputed financial analysts as well as picking up valuable gossip from the stock market floor. The task of financial journalists is to keep an eye, report and comment on the performance of major companies in their field of specialism and to present their descriptions and evaluations in ways that can be quickly digested by readers who require unambiguous and reliable information (cf. Roush 2009). Newspaper and online articles on stocks and shares are read and evaluated by people who want to have a sense of current trends with regard to some particular company or industrial sector, or very often with regard to the stock market as a whole. This journalism helps readers develop a feeling for how the economy is developing, as well as a feeling for how other possibly more authoritative and trustworthy - players are feeling in terms of hopefulness or despondency. It is in this force field of feelings and feelings about feelings that journalists have taken to writing of sentiment and confidence.

\section{EMOTIONS AND THE STOCK MARKET: VIEWS FROM PSYCHOLOGY AND DISCOURSE ANALYSIS}

\subsection{Efficient Markets Model}

The notion that emotionality is a harmful influence underlies a well-known attempt to exclude emotions from financial decisions, the Efficient Markets Model of Fama (1970, 1991). In this model, the totality of investors is seen as acting rationally, basing decisions on historical data, i.e. the past performance of shares. If there are random movements in a stock price deriving from emotional factors, perhaps because of some unexplainable hype, these will quickly be nullified: the stock market is seen as self-correcting and thus having its own logic. Infrequent cases of irrational behaviour by so-called "noise traders" (Black 1986) are in this view countered by a majority of rational agents.

\subsection{Behavioural Finance Research}

An opposing view is taken by Behavioural Finance Research (Schleifer 2000), which examines the effect of cognitive and specifically emotional factors on individuals' financial decisions and on the stock market as a whole. This approach has emphasized 
the value as well as the dangers of the human propensity to rely on habits, to apply rules of thumb, to think stereotypically and analogically and to put faith in anecdotes and word of mouth. Hey and Morone (2004) have identified the "herding instinct" as a relevant factor here, describing how individuals act collectively without any leadership, like birds in a swarm. Kahneman and Tversky (1979) pinpoint various trends in behaviour, notably "loss aversion", which reflects humans' reactions to gains and losses: winning $\$ 5$ is much less emotionally affecting than losing $\$ 5$, and this has tangible repercussions on investment choices. One of these is the "disposition effect" (Shefrin and Statman 1985), which leads investors to sell winning shares and to hold on to losing ones, behaviour that can be shown to be irrational and counter-productive. Although this line of research into human behaviour on the stock market explicitly recognizes human feelings as playing a part in financial decision-making, the major results have stressed the downside of emotions, namely their potential for leading to irrational behaviour.

\subsection{Emotions, decision-making and discourse analysis}

Research into the actual impact of emotions on financial trading is still rather limited (see Ackert, Church and Deaves 2003 for a provisional assessment). However, it has been established neurologically (cf. Damasio 1994) that emotions are crucial to higherlevel cognition in general and to the actions that follow from human choices (Frijda 1986). Emotions must therefore be expected to have an impact on financial decisions, too, as is indirectly demonstrated by Shiv et al. (2005), who show that patients with certain emotion-affecting neural dysfunctions tend to make objectively better investment decisions than patients with non-emotional dysfunctions or indeed persons with no neural dysfunctions. In discourse analysis, too, there has for many years been a tendency to overlook the role of emotions, a trend that has been reversed by a recent rise in the attention paid to the impact of emotions on language use (Foolen 2012); this is reflected for example in the emergence of Appraisal Theory (Martin and White 2005; see $\S 5$ below), which gives due recognition to the underlying presence of affect in written communication. Alba-Juez (fc.) traces this "emotional turn" in linguistics and proposes formal equations that capture the presence of emotion in evaluative language.

\section{SENTIMENT AND CONFIDENCE IN GENERAL USAGE}

Any attempt to consider the words sentiment and confidence in Financial English must be carried out against the backdrop of their use in general parlance. Sentiment was borrowed into Late Middle English from French, where sentiment was and still is the basic word for 'feeling'. In the $17^{\text {th }}$ and $18^{\text {th }}$ centuries, it denoted various emotions, often specifically amatory feelings or inclinations (OED, s.v. sentiment). More recently, however, it has been applied to "those feelings which involve an intellectual element" (OED, ibid.); in fact, the older sense is found "[n]ow chiefly in derisive use, conveying an imputation of either insincerity or mawkishness" (OED, ibid.). The word sentiment in its contemporary use is thus particularly appropriate for denoting feelings that are in some way associated with rationality, and it is therefore perhaps no surprise that this word is popular with journalists (and others) who write about financial markets where, as we have seen, emotion and reason are in a constant dialectic. 
The two faces of sentiment are apparent in the definition found on WordNet, the major lexical database for the English language (http://wordnetweb.princeton.edu/ perl/webwn), which distinguishes two senses:

S: (n) sentiment (tender, romantic, or nostalgic feeling or emotion)

S: (n) opinion, sentiment, persuasion, view, thought (a personal belief or judgment that is not founded on proof or certainty) "my opinion differs from yours"; "I am not of your persuasion"; "what are your thoughts on Haiti?"

In the first sense, Wordnet gives the direct hypernym 'feeling', in the second 'belief'.

As for confidence, this word has a number of senses, as is apparent from its WordNet definition:

S: (n) assurance, self-assurance, confidence, self-confidence, authority, sureness (freedom from doubt; belief in yourself and your abilities) "his assurance in his superiority did not make him popular"; "after that failure he lost his confidence"; "she spoke with authority"

S: (n) confidence (a feeling of trust (in someone or something)) "I have confidence in our team"; "confidence is always borrowed, never owned"

$\mathrm{S}$ : (n) confidence (a state of confident hopefulness that events will be favorable) "public confidence in the economy"

$\mathrm{S}$ : (n) confidence, trust (a trustful relationship) "he took me into his confidence"; "he betrayed their trust"

S: (n) confidence (a secret that is confided or entrusted to another) "everyone trusted him with their confidences"; "the priest could not reveal her confidences"

Disregarding the fifth sense, which identifies a countable use of confidence, we may note that confidence, like sentiment, has a rational/cognitive as well as an emotional side: the direct hypernym for the first sense is certainty and the direct hypernym of certainty is cognitive state of mind, while for the second sense the direct hypernym is security; the direct hypernym of security is fearlessness, and the direct hypernym of fearlessness is feeling. The third and fourth senses both ultimately denote a state: the hypernym chains are confidence $>$ hopefulness $>$ condition $>$ state and friendship $>$ relationship $>$ state respectively. It is primarily the third sense, of course, which is reflected in the use of the word in Financial English.

What is apparent from this glance at the recognized general meanings of sentiment and confidence and their place in the network of English words is that, although they share the property of spanning the emotion-reason divide, they are far from being synonyms in their general use. Not only do they differ in their definitions, they also display distinct values for valence. Valence is a term used in the study of emotions to denote the hedonic value of an emotion (Russell 1980). Having originally been used to partition emotions into two classes, positive (e.g. joy) or negative (e.g. anger), the notion of valence, partially thanks to neuropsychological research (Briesemeister et al. 2012), is now being envisaged as a continuum, with degrees of deviation from neutral valence (cf. the degrees of happiness identified as contentment - joy - ecstasy) as well as recognized cases of ambivalence (cf. the 'bitter-sweet' nature of nostalgia, mentioned by WordNet with respect to sentiment). What WordNet reveals, then, in line with the definitions in the $O E D$, is that sentiment is associated with emotion of mildly positive or possibly ambi- 
valent valence, while confidence is a word with a stronger and exclusively positive valence, being connected with self-assurance, self-belief and reliance on others and the good feelings that arise from these qualities. On this basis, let us now move on to consider how the word confidence has been treated in the study of the language of evaluation in systemic-functional linguistics (SFL) known as Appraisal Theory (Martin and White 2005; Bednarek 2008).

\section{CONFIDENCE IN SFL APPRAISAL THEORY}

As shown in $\S 4$, sentiment is etymologically and in current parlance a word from the language of emotion, being used to denote feelings in general, with a certain connotation of implications for rational behaviour. Although sentiment is not a word treated by either Martin and White (2005) or Bednarek (2008), both works deal with confidence, a word that as we have seen overlaps with the realm of emotion talk. It is accordingly classified by Martin and White (2005) as denoting a type of Affect (one of the five types of Appraisal they distinguish). Confidence is located in their typology of Affect on the In/security dimension, which in their words is "concerned with ecosocial well-being" (2005: 49). For them, the emotions Confidence and Trust have positive valence ${ }^{1}$ and are opposed to Disquiet and Surprise respectively. In addition, Confidence and Disquiet are "undirected" (2005: 47), i.e. they identify a disposition or character trait, while Trust and Surprise are directed, involving a momentary surge of emotion: John is a confident person thus falls under Confidence while John is confident about the result is classified, because of the following prepositional phrase (PP), under Trust. Martin and White's classification is shown in Table 1.

Table 1

Martin and White (2005)'s classification of In/security

\begin{tabular}{|l|l|l|}
\hline & \multicolumn{1}{|c|}{ Security } & \multicolumn{1}{c|}{ Insecurity } \\
\hline Undirected & Confidence & Disquiet \\
\hline Directed & Trust & Surprise \\
\hline
\end{tabular}

Bednarek (2008: 160), also working in the general framework of Appraisal Theory, criticizes the opposition between trust and surprise, which she rightly does not see as polar opposites. Appealing explicitly to the distinction made by students of emotion between positive and negative valence (2008: 157; see also $\$ 4$ above), she proposes a modified classification, shown in Table 2, in which Martin and White's Surprise is replaced by Distrust (an explicit antonym of Trust) and an analogous pair are introduced for Undirected In/security, namely Quiet and Disquiet.

Table 2

Bednarek (2008)'s classification of In/security

\begin{tabular}{|l|l|l|}
\hline & \multicolumn{1}{|c|}{ Security } & \multicolumn{1}{c|}{ Insecurity } \\
\hline Undirected & Quiet (= "emotional calm") & Disquiet \\
\hline Directed & Trust & Distrust \\
\hline
\end{tabular}

${ }^{1}$ Martin and White (2005) do not use this term, but they do repeatedly talk of positive and negative Affect. 
While Bednarek's proposal succeeds in identifying polar opposites, her explanation of Quiet as "emotional calm" (2008: 156) is an unfortunate choice of expression to the extent that it suggests confidence is to be located on a kind of neutral emotional baseline of calm and quietude ${ }^{2}$. Her alternative to Martin and White loses the positive, active connotations of confidence, for which reason I prefer to retain Confidence rather than Quiet at the positive pole of the $\mathrm{In} / \mathrm{security}$ dimension, as in Table 3.

Table 3

Revised classification of In/security

\begin{tabular}{|l|l|l|}
\hline & \multicolumn{1}{|c|}{ Security } & \multicolumn{1}{c|}{ Insecurity } \\
\hline Undirected & Confidence & Disquiet \\
\hline Directed & Trust & Distrust \\
\hline
\end{tabular}

The fact that confident has positive valence is apparent from the test "confident but ...", where the adjective after but must have negative valence: consider confident but cocky, confident but imperfect (both examples from the British National Corpus) as against *confident but happy, ${ }^{*}$ confident but admirable, etc.

\section{HYPOTHESIS}

On the basis of the discussion in $\S 4$ and $\S 5$, it is justified to state that sentiment and confidence are nouns that in general use share the property of operating where reason and emotion converge but which differ quite markedly in their valence: whereas sentiment is mildly positive or even ambivalent in its valence, confidence is strongly biased towards positive valence. Since it is reasonable to suppose that the general characteristics will carry over to their use in the more technical context to be examined in this article, the hypothesis to be tested is thus that in financial journalism as represented by the corpus to be described in $\S 7$, the words sentiment and confidence will be used in distinct contexts, with sentiment being appropriate for neutral use and confidence for positive use. This will be examined through an examination of the collocations and semantico-syntactic distribution of the two words, both in the clause and within the noun phrase.

\section{METHODOLOGY: THE CORPUS}

The corpus used for this research is the Hong Kong Financial Services Corpus, produced by the Research Centre for Professional Communication in English of the Hong Kong Polytechnic University and available on line at http://rcpce.engl.polyu.edu.hk/ HKFSC/. It currently (July 2017) contains 7,341,937 words. It has been used quite extensively in corpus linguistics, notably by Cheng (2012). The advantage of a specialized corpus like this is that it gives insight into the particularities of a single register, in this case that of financial services in general and financial journalism in particular. The corpus

\footnotetext{
2 Russell (1980) distinguishes another dimension orthogonal to the valence dimension, Arousal. Quiet would correspond to minimal Arousal.
} 
as offered on line contains a number of duplicate entries, due to the fact that the same text regularly appears in different news outlets or is copied verbatim from business reports into news reports. After all the duplicate entries were removed, the number of tokens of each of the target words was (in July 2016, when the research was conducted) as follows:

Sentiment: 131 tokens

Confidence: 485 tokens

\section{SENTIMENT IN THE CORPUS}

In order to classify the occurrences of the uncountable noun sentiment in the corpus for the purpose of comparing it with confidence, it is important to develop a model of the semantic frames in which it occurs and the grammatical positions of the corresponding noun phrases (NPs). Just as share prices can be static ("no change") or dynamic, either rising or falling, so sentiment, too, can occur in either a static or a dynamic state of affairs. In a static state of affairs, the construction chosen is generally intransitive and tends to involve a descriptive adjective. In a dynamic state of affairs, sentiment occurs either in the guise of a driving force (the 'actor') or, much more frequently, as something that is affected by other factors (as an 'undergoer'); for the macroroles 'actor' and 'undergoer', see Van Valin (2005). The undergoer appears grammatically either as the 'unaccusative' subject of an intransitive clause or as the accusative object of a transitive clause; for the term 'unaccusative' describing the non-agentive subject of an intransitive verb, see Perlmutter (1978). Sentiment otherwise occurs in PPs that modify the clause in various ways.

The following examples extracted from the corpus show sentiment occurring in a static state of affairs:

(1) Sentiment does appear currently to be somewhat frail.

(2) ... when sentiment is one-sided, which is often the case in financial markets, exchange rate overshooting can be quite common.

(3) ... the market sentiment remained bearish on concern the Bank of Japan would raise interest rates.

Sentiment here is described on the basis of the authors' perceptions (... does appear), their experience (... which is often the case) or their observation of other emotions (concern ... raise interest rates).

Turning now to dynamic examples, we first see sentiment occurring as an actor, either causing investors' behaviour to change in some way or impeding it from doing so:

(4) The stock market was buoyed by optimistic sentiment as investors poured in capital.

(5) This positive sentiment will hopefully translate into positive territory.

(6) ... poor equity market sentiment toward incumbent cellular operations in Europe necessitated postponement of the proposed initial public offering.

In (4) positive sentiment "buoys" the stock market (causing prices to rise) and in (5) it is hoped that the same will happen, while in (6) negative sentiment hinders business activity. 
In the next set of examples, sentiment is seen as undergoing change and occurs as an unaccusative subject:

(7) ... emerging markets where steady growth in consumer sentiment continues.

(8) Sentiment in the residential market weakened in the financial year 2006.

(9) The recovery of investor sentiment has seen more money from institutional investors.

In (7) sentiment continues to grow, in (8) it weakens and in (9), which involves a nominalization of the intransitive verb recover with an unaccusative undergoer argument, sentiment improves after a weaker period. Sentiment here is metaphorized as an organic entity that can grow, weaken (see also example (1) above) and then recover its strength again; cf. Charteris-Black 2004: 135 on the conceptual metaphor THE ECONOMY IS AN ORGANISM.

In the final set of examples, which represents the dominant semantico-syntactic option in the corpus, sentiment is presented as an accusative object, undergoing the influence of some event in the news:

(10) A flurry of corporate activities also boosted sentiment.

(11) The gradual step-up of interest rates in Hong Kong has dampened buying sentiment.

(12) ... pushed around by big players, particularly those in a position to influence market sentiment.

(13) ... [using] information from Hong Kong dollar option prices to monitor market sentiment regarding the Hong Kong dollar.

The effect of the influence may be positive as in (10), negative as in (11) or neutral as in (12); a final use involves financiers' (and journalists') observation of sentiment as in (13).

Finally, sentiment can occur in NPs that are the complements of prepositions, as in (14) to (16); the function of the PPs is to situate news facts in the context of market traders' feelings (cf. the word concerns in (16)) about the matter at hand:

(14) ... property development sales in Hong Kong were lower, pending improved market sentiment.

(15) Korea's KOSPI started the year strongly amid strong domestic sentiment.

(16) ... the effect of continuing interest rate and geopolitical concerns on market sentiment.

As some of the data have already shown, sentiment can occur in NPs of varying complexity. Let us recognize the following seven NP-internal positions, four before the syntactic head sentiment and two after it:

\section{Grounding Epithet Classifier $\mathbf{N}\left({ }^{\prime}\right)$ SENTIMENT Complement Adjunct}

An imaginary example NP with all slots filled (nothing as complete as this is found in the data) would be (17):

(17) [recent] [positive] [local] [private investor] [sentiment] [towards emerging markets] [in Hong Kong]

Grounding expressions include \{recent, current, immediate, then and serve to anchor the NP to the time dimension; epithets are descriptive/evaluative and include positive, upbeat, optimistic, improved, improving, buoyant, good $\}$ (all positive) and \{nega- 
tive, adverse, nervous, weak, poor $\}$ (all negative); classifiers indicate the range of the sentiment and include \{economic, public, local, global, overall, general, domestic, international, overseas $\} ; \mathrm{N}(')$ indicates either a single noun $(\mathrm{N})$ or a nominal group $\left(\mathrm{N}^{\prime}\right)$ that enters into a nominal compound with sentiment, as in market sentiment or consumer spending sentiment respectively, and includes \{market, property market, equity market, financial market, consumer, consumer spending, consumption, investor, private investor, equity, buying, investment, performance\}. Whereas these nominal compounds generally identify the segment of the market to which the sentiment pertains, the complement takes the form of a PP and typically indicates what the sentiment is about and includes \{about $\mathrm{x}$, against $\mathrm{x}$, for $\mathrm{x}$, of $\mathrm{x}$, on $\mathrm{x}$, regarding $\mathrm{x}$, towards $\mathrm{x}$, while the adjunct indicates the spatio-temporal parameters of the sentiment, including (in $\mathrm{y}$ (a time or place), on $\mathrm{y}$ (a day)\}.

\section{CONFIDENCE IN THE CORPUS}

Let us now consider the occurrences of the uncountable noun confidence in the corpus from the same analytical perspective.

The following examples show confidence occurring in a static state of affairs:

(18) Confidence in Hong Kong remains fragile and fickle.

(19) ... the markets were beginning to fail and local confidence was in jeopardy.

(20) There is a high degree of confidence that the leadership will be able to deliver.

Confidence is in these examples described as being weak, endangered or strong on the basis of the writer's assessment of investors' feelings, these in turn having been induced from their actions (in terms of buying and selling).

Turning now to dynamic examples, we find confidence occurring as an actor that has an impact on investors' behaviour:

(21) There was no significant evidence of capital flight triggered by reduced confidence.

(22) Improving foreign and domestic confidence have (sic) reignited the Japanese market.

(23) Buoyant consumer confidence will continue to underpin retail spending.

In these examples, confidence is conceptualized as a force triggering, reigniting or underpinning economic activity.

Confidence can also be seen as undergoing change, firstly in its occurrences as an unaccusative subject:

(24) Confidence on financial markets returned after the signing of the Joint Declaration.

(25) [Investment will] flow back into the region as confidence levels also edge upward.

(26) A rebound in public confidence will continue to boost local economic activities.

In (24) confidence comes back, in (25) it slowly improves and in (26), which involves a nominalization of the intransitive verb rebound, it improves after a weaker period.

Confidence can also occur as an accusative object (or the corresponding subject of a passive clause, as in (27)), undergoing the influence of some event in the news:

(27) Buyers' confidence is bolstered by strengthening economic prospects.

(28) Chaos in the interbank market ... would in turn damage confidence on [sic] the banking system as a whole. 
(29) Dialogue will be key to maintaining stakeholder confidence as we depart from business as usual.

The effect of the influence may be positive as in (27), negative as in (28) or neutral as in (29). In addition, confidence can occur as an (accusative) 'effected object', i.e. as coming into existence as a result of the action, as in (30) and (31):

(30) Insurance is an ingenious tool conceived on the basis of pragmatism and collaboration, ... injecting confidence for investors to take on new ventures.

(31) HKEx will continue to strive to engender trust and confidence by pursuing ongoing enhancements.

Whereas we also found sentiment occurring in NPs that are the complements of prepositions (cf. examples (14) to (16) in $\S 8$ above), this does not apply to confidence.

Like sentiment, the noun confidence can also occur in NPs of varying complexity. The NPs encountered in the corpus display no fewer than eight positions, as follows:

\section{Determiner Epithet Classifier N CONFIDENCE Complement Adjunct Postmodifier}

An imaginary example of an NP with all slots filled (again, nothing as complete is found in the data) would be:

(32) [the market's] [stronger] [long-term] [business] [confidence] [in Hong Kong] [at present] [that is displayed in greater inward investment]

Determiners include the quantifiers every and more but also specifying genitives like the market's; epithets are descriptive and evaluative and include strong(er), renewed, restored, growing, rising, etc.\} (positive) and \{poor, low, declining, little, etc. $\}$ (negative); classifiers indicate the range of the confidence and include \{public, general, domestic, international, overseas, worldwide, long-term, etc. $;$; $\mathrm{N}$ indicates a single noun that enters into a compound with confidence, e.g. investor confidence, and includes \{market, investor, investment, stakeholder, client, etc.\}. Whereas these classifiers generally identify the segment of the market to which the sentiment pertains, the complement, if present, takes the form of a PP or of a that-clause and indicates what the confidence is directed to (see $\S 5$ above on 'directedness'); the most common PP is one starting with the preposition in (40.5\% of the instances of confidence; cf. (32)), but other prepositions are used, including $\{a s$ to, for, on, towards $\}$. The adjunct generally indicates the temporal parameters of the confidence, again taking the form of a PP, and the postmodifier is a relative clause or non-finite participial construction such as which that implies or expressed by international investors respectively.

\section{DISCUSSION}

The two preceding sections have shown that the nouns sentiment and confidence are used in the corpus of texts in financial services in very similar ways. Both can appear in static and dynamic semantico-syntactic contexts, and within the dynamic contexts either as actor or as undergoer, and in the latter case either as an unaccusative subject or as an accusative object. In the static contexts, both sentiment and confidence are typically classified according to their strength; in the actor contexts, both sentiment and confidence are seen as enabling and strengthening investor activity; in the unaccusative 
contexts, they both improve, deteriorate or remain unchanged; in the accusative contexts, they both are improved or deteriorated by some characteristic of the stock market. Only in this last context do differences emerge: verbs of observation (gauge, monitor, ...) are exclusively found with sentiment (see example (13) in $\S 8$ above), while verbs of creation (engender, inspire, ...), which take an effected object, are only found with confidence (see examples (30) and (31) in $\$ 9$ above). Whereas the first generalizations go against the hypothesis of difference, the final generalizations support it, in that gauging or monitoring sentiment is neutral while engendering or inspiring confidence must be understood in a positive sense.

Another point of similarity is that both sentiment and confidence welcome the construction of complex NPs with multiple modifiers before and after the head. The functional templates show a high degree of parallelism, as shown in Table 4.

Table 4

The maximum structure of NPs with sentiment or confidence as their head nouns

\begin{tabular}{|c|c|c|c|c|c|c|c|}
\hline Grounding & Epithet & Classifier & $\mathrm{N}\left({ }^{\prime}\right)$ & SENTIMENT & Complement & Adjunct & \\
\hline Determiner & Epithet & Classifier & $\mathrm{N}$ & CONFIDENCE & Complement & Adjunct & Postmodifier \\
\hline
\end{tabular}

The differences between the two are rather minor: grounding expressions and determiners share the function of anchoring the NP to the discourse context; the distinction between $\mathrm{N}(')$ and $\mathrm{N}$ reflects the fact that sentiment can enter more complex nominal compounds than confidence; and the exclusive presence of the Postmodifier function with confidence may reflect the greater complexity of compounding permitted by sentiment, i.e. there is a rough equivalence between, say, the confidence expressed by international investors (Determiner-CONFIDENCE_-Postmodifier) and international investor sentiment $\left(\mathrm{N}^{\prime}\right.$ - SENTIMENT).

There are certainly some differences that are worth pointing to. As anticipated in $\S 5$, there is a distinction between confidence as an undirected disposition and confidence as a directed type of trust. Since in a variable stock market, confidence is predominantly directed to particular companies, sectors or indeed the economy as a whole, writers as expected take advantage of the possibility of complementing confidence with a PP introduced by in, a 'directed' construction not available for sentiment. Another difference is that confidence is presented as quantifiable (with frequent talk of degrees or levels of confidence), reflecting the gradable nature of the adjective confident; sentiment, by contrast, is not quantifiable in this sense, as follows from its greater neutrality.

Where the two words are clearly similar is in varying along a scale that reflects expected or already existent rises and falls in share prices. Both with sentiment and with confidence, this is typically metaphorized in terms of variations in the strength, liveliness or health of an organism: both notions are said to be strong and capable of triggering and supporting growth or else to be weak and to exacerbate losses; similarly, both can recover and revive from periods of weakness, or decline and succumb to bad news; if nothing of note happens, then both sentiment and confidence are shored up and consolidated.

In many aspects of financial discourse, no practical difference is observed. Among the best known international indexes are the OCDE's Business Confidence Indicator, the Acertus Market Sentiment Indicator, the Gallup Economic Confidence Index, and the 
European Commission's Economic Sentiment Indicator (ESI). As will be noted, the terms sentiment and confidence are used here interchangeably. In fact, the Commission's Economic Sentiment Indicator (ESI) is defined ${ }^{3}$ as a composite indicator made up of five sectoral confidence indicators with different weights: the Industrial confidence indicator, the Services confidence indicator, the Consumer confidence indicator, the Construction confidence indicator and the Retail trade confidence indicator.

The conclusion is therefore that the hypothesis formulated in $\S 6$ that the words sentiment and confidence will be treated distinctly in the sample of financial discourse formed by the corpus examined is to a very large extent to be rejected.

\section{CONCLUSIONS}

My research has shown that sentiment and confidence are terms taken from the stock of "emotion words" and are extensively used in the discourse of financial journalists and other providers of financial services. Although the two words are quite distinct in everyday parlance, they are used almost synonymously in Financial English to describe the complex of expectations and feelings that exist in the community of investors. It is true that these expectations derive from a dispassionate and increasingly computer-based monitoring of company performance and from risk-laden extrapolations from past returns on investments to future outlooks. In addition, confidence or sentiment indicators (we have seen that the terms are used interchangeably) are algorithmically linked to indicators referencing other variables such as industrial production. Nevertheless, emotions can no more be banished from stock markets than from any other realm of human action and are key to the decision-making that drives the upsurges and downturns of share indices. It is these emotions that writers are tapping into when they use the emotion words sentiment and confidence to describe conjunctures of economic circumstances.

Further research into this area could benefit from considering the use of emotion terms like sentiment and confidence in social media. Twitter and comparable media are rapidly replacing financial journalism, and it would be revealing to know whether the terms sentiment and confidence have been retained in these new media and display the same range of meanings and uses.

(C) J. Lachlan Mackenzie, 2018

\section{REFERENCES}

Ackert, L.F., Church, B.K., \& Deaves, R. (2003). Emotion and financial markets. Federal Reserve Bank of Atlanta Economic Review, 2nd Quarter, 33- 41.

Alba-Juez, L. (Fc.) Emotion and appraisal processes in language: How are they related? In Gómez González, M.A. \& J.L. Mackenzie (eds.; subm.), The Construction of Discourse as Verbal Interaction. Amsterdam: John Benjamins.

Bednarek, M. (2008). Emotion talk across corpora. Houndsmills/New York: Palgrave Macmillan. Black, F. (1986). Noise. Journal of Finance, 41(3), 529-543. doi: 10.1111/j.1540-6261.1986.tb04513.x.

Briesemeister, B.B., Kuchinke, L. \& Jacobs, A.M. (2012). Emotional valence: A bipolar continuum or two independent dimensions? Sage Open, 2012 (2), 1-12. doi: 10.1177/2158244012466558.

${ }^{3}$ See http://ec.europa.eu/eurostat/statistics-explained/index.php/Glossary:Economic_sentiment indicator_(ESI). 
Charteris-Black, J. (2004). Corpus approaches to critical metaphor analysis. Houndsmills/New York: Palgrave Macmillan.

Cheng, W. (2012). Exploring corpus linguistics: Language in action. London/New York: Routledge. Damasio, A.R. (1994). Descartes' error: Emotion, reason, and the human brain. New York: Putnam.

Fama, E.F. (1970). Efficient capital markets: A review of theory and empirical work. Journal of Finance, 25(2), 383 - 417. doi: 10.1111/j.1540-6261.1970.tb00518.x.

Fama, E.F. (1991). Efficient capital markets: II. Journal of Finance, 46(5), 1575-1617. doi: 10.1111/j.1540-6261.1991.tb04636.x.

Feldman, R. (2013). Techniques and applications for sentiment analysis. Communications of the ACM, 56(4), 82-89. doi: 10.1145/2436256.2436274.

Foolen, A. (2012). The relevance of emotion for language and linguistics. In Foolen, A., U.M. Lüdtke, T.P. Racine \& J. Zlatev (eds.), Moving Ourselves, Moving Others: Motion and Emotion in Intersubjectivity, Consciousness and Language. Amsterdam/Philadelphia: John Benjamins. 349—368. doi: $10.1075 /$ ceb.6.13foo

Frijda, N.H. (1986). The emotions. Cambridge: Cambridge University Press.

Hey, J.D., \& Morone, A. (2004). Do markets drive out lemmings - or vice versa? Economica, $71(284), 637-659$.

Kahneman, D., \& Tversky, A. (1979). Prospect theory: An analysis of decision-making under risk. Econometrica, 47(2), 171-185.

Martin, J.R., \& White, P.R.R. (2005). The language of evaluation. Houndmills/New York: Palgrave Macmillan.

Perlmutter, D.M. (1978). Impersonal passives and the Unaccusative Hypothesis. Berkeley Linguistics Society, 4, 157-189. doi: 10.3765bls.v4i0.2198.

Roush, C. (2009). Business journalism. In C.H. Sterling (ed.), Encyclopedia of journalism, Vol. 1, 225-229. Los Angeles etc.: Sage.

Ruiz-Martínez, J.M., Valencia-García, R., \& García-Sánchez, F. (2012). Semantic-based sentiment analysis in financial news. In Proceedings of First International Workshop on Finance and Economics on the Semantic Web (FEOSW 2012). Heraklion (Greece). 38-51.

Russell, J.A. (1980). A circumplex model of affect. Journal of Personality and Social Psychology, 39(6), 1161-1178. doi: 10.1037/h0077714.

Shefrin, H., \& Statman, M. (1985). The disposition to sell winners too early and ride losers too long: Theory and evidence. Journal of Finance, 40(3), 777-790.

Shiv B., Lowenstein G., Bechara A., Damasio, H., \& Damasio A. (2005). Investment behavior and the negative side of emotion. Psychological Science, 16, 435-439. doi: 10.1111/j.09567976.2005.01553.x.

Shleifer, A. (2000). Inefficient markets: An introduction to behavioral finance. Oxford: Oxford University Press.

Van Valin, Jr., R.D. (2005). Exploring the syntax-semantics interface. Cambridge: Cambridge University Press.

\section{Article history:}

Received: 07 July 2017

Revised: 12 August 2017

Accepted: 15 August 2017

\section{For citation:}

Mackenzie, J. Lachlan (2018). Sentiment and Confidence in Financial English: A Corpus Study. Russian Journal of Linguistics, 22 (1), 80-93. doi: 10.22363/2312-9182-2018-22-1-80-93. 


\title{
Bionote:
}

J. LACHLAN MACKENZIE is Emeritus Professor of Functional Linguistics at VU Amsterdam. With a PhD from the University of Edinburgh (1978), his career was in the Netherlands, working closely with Simon Dik, Kees Hengeveld and many others on the development of Functional Grammar (FG) and Functional Discourse Grammar (FDG). He is currently associated with three research groups in Iberia: SCIMITAR (Santiago de Compostela), EMO-FUNDETT (Madrid) and CELGA-ILTEC (Coimbra). His research interests range from functionalist linguistics to pragmatics, discourse analysis and emotion in language. Key co-publications: Functional Discourse Grammar (OUP 2008) and Pragmatics: Cognition, Context and Culture (McGraw Hill 2016). Contact information: lachlan_mackenzie@hotmail.com

\section{«НАСТРОЕНИЕ» И «ДОВЕРИЕ» В ФИНАНСОВОМ АНГЛИЙСКОМ: ИЗУЧЕНИЕ КОРПУСА АНГЛИЙСКОГО ЯЗЫКА}

\author{
Дж. Лахлан Маккензи \\ Амстердамский свободный университет \\ De Boelelaan 1105, 1081 HV Amsterdam, Нидерланды
}

\begin{abstract}
В мире финансов слова «настроение» и «доверие» часто используются, чтобы побудить инвестора/инвесторов приобрести акции на рынке или вложить деньги в ценные бумаги. В статье рассматривается употребление этих двух слов в финансовой журналистике на материале электронного корпуса финансовых услуг Гонконга. Автор проверяет гипотезу о том, что в финансовом языке данные слова имеют свои особенности. Опираясь на положения функциональной семантики и теории оценки, автор анализирует, как они используются в придаточных и номинативных предложениях, и приходит к выводу, что слова «настроение» и «доверие» часто используются в финансовом языке в качестве синонимов. Делается вывод о том, что, употребляя эти слова, автор текстов осознает значение эмоций как важного фактора в принятии решений.
\end{abstract}

Ключевые слова: эмоции, финансовый анализ, грамматика, журналистика, семантика, доверие, настроение

\section{История статьи:}

Дата поступления в редакцию: 07 июля 2017

Дата принятия к печати: 15 августа 2017

\section{Для цитирования:}

Mackenzie, J. Lachlan (2018). Sentiment and Confidence in Financial English: A Corpus Study. Russian Journal of Linguistics, 22 (1), 80—93. doi: 10.22363/2312-9182-2018-22-1-80-93.

\section{Сведения об авторе:}

Дж. ЛАХЛАН МАККЕНЗИ - заслуженный профессор, профессор функциональной лингвистики Амстердамского свободного университета. Получил степень доктора в Эдинбургском университете (1978 г.). Работал в Нидерландах совместно с Саймоном Диком, Кизом Хенгевельдом и другими учеными над созданием функциональной грамматики и функциональной дискурсивной грамматики. В настоящее время он сотрудничает с тремя исследовательскими группами: SCIMITAR (Сантьяго де Компостела, Испания), EMO-FUNDETT (Мадрид, Испания) и CELGA-ILTEC (Коимбра, Португалия). Сфера научных интересов: функциональная лингвистика, прагматика, дискурс-анализ, эмоции в языке. Основные публикации: Functional Discourse Grammar (Oxford University Press, 2008), Pragmatics: Cognition, Context and Culture (McGraw Hill 2016). Контактная информация: lachlan_mackenzie@hotmail.com 